\title{
EFFECT OF FUELS ON THE PISTON RING OF THE FLEXFUEL ENGINES
}

\author{
Rogério da Silva Nunes ${ }^{1}$, Mauro Carlos Lopes Souza ${ }^{2}$, Rodrigo Felix de Araujo \\ Cardoso $^{3}$, Neyda de la Caridad Om Tapanes². \\ ${ }^{1}$ MOTOR SET Retífica de Motores Ltda, ${ }^{2}$ UEZO - Fundação Centro Universitário \\ Estadual da Zona Oeste, ${ }^{3} \mathrm{CBPF}$ - Centro Brasileiro de Pesquisas Físicas. \\ E-mails: rogerio-sn@hotmail.com; mauroclsouza@hotmail.com; rfelix@cbpf.br; \\ neydaom@yahoo.com;
}

\begin{abstract}
The present study, describes the characteristics of wear of two specimens groups of piston rings of the first piston groove of internal combustion engines. Gasoline engines rings are the first group to be investigated and rings of flex-fuel engines are the second group investigated. Thus, the main objective of this study is to investigate potentially irregular wear between these two engine groups, according to their technologies, regarding the use of gasoline, ethanol or blend fuel in any proportion. In the method used, the piston rings were collected in an automobile repair and engine reconditioning shop, then they were properly cataloged and marked. The specimens are intentionally of high mileage, to achieve the research purposes. The investigation was divided into three steps. The first step involved the measurement of ring heights, thicknesses and rings outer diameters, to compare them with the original measurements provided by the manufacturers and to compare the groups of gasoline engine and flex-fuel engine. In the second step, the rugosimetric parameters of the specimen surfaces were checked with a rugosimeter, for comparison between the two groups studied. Subsequently, in the third step, using a scanning electron microscope (SEM), microscopic analysis was performed on the contact surface coating of the piston rings. It was found that, indeed, there are differences between the two groups of piston rings with respect to wear. It was concluded that the wear of the rings of the two groups of engines is quantitatively similar. However, as for the rugosimetric analysis, a great qualitative variation was observed in the rings of flexfuel engines compared with gasoline engine rings.
\end{abstract}

\section{INTRODUCTION}

In the 70's, on November 14, 1975, during the first oil crisis, the National Ethanol Program (known as PRÓ-ÁLCOOL) was launched by the Brazilian government to promote the gradual replacement of gasoline-powered engines by ethanol-powered engines.

In 1979, the world went through a second oil crisis, but Brazil was not completely dependent on fuel oil anymore, since it had developed its own technology of internal combustion engines powered by hydrated ethyl alcohol (HEA) or simply ethanol. 
Although a vast amount of knowledge of this technology has been gained, concerning the materials used in the components of ethanol engines, many of the more conservative users, or those not believing in the continuity of the PRÓÁLCOOL project, opted for purchasing vehicles with gasoline engines, a fact that would have made ethanol-powered engines to disappear soon. [1].

In 2003, the Brazilian automobile industry presented a solution in order to prevent all the years of efforts put in research and development of ethanol-powered engines from being wasted: it decides to combine all the knowledge acquired on ethanol engines with the knowledge of gasoline engines by launching engines with flex-fuel technology. [2]. Although they were launched in 2003, after 16 years of continuous development, flex-fuel engines had not yet reached their full technological maturity, still needing solutions or improvements to the following problems: cold start; intake manifold; evaporative emissions system; emission of unburnt ethanol and aldehydes; combustion chamber, catalytic converter; fuel tank; discharge or exhaust pipe; motor oil; speed of ethanol combustion; time available for combustion; mechanical and chemical properties of the materials used in the fabrication of the engine; alteration of the tribological system environment; more complex engine calibration; vibrations; creation of gum due to ethanol; lack of miscibility of gasoline with ethanol; cylinder washing and lubricant dilution during cold start; corrosive environment and low lubricity. [3]. In addition, there is a specific problem that intrigues the engineers specialized in surface engineering, that is, the wear of flex-fuel engines, which led to the creation of a research group called TRIBOFLEX.

There are other factors involved, such as compression ratio, since ethanol and gasoline are chemically very different from each other, requiring different compression ratios and temperature conditions to generate as much energy as possible per cycle or combustion and less emission of pollutants. The thermal degree of the spark plug can also be mentioned as a problem for heat dissipation in the combustion chamber. Developing an intermediate-temperature spark plug that meets the requirements and initiates efficient combustion with any fuel or mixes them together is still a huge challenge.

The tribological challenges are, as they were, some of the most complex problems, as tribology requires in-depth research into materials, lubricants, temperatures, wear, friction and contact surfaces, as well as knowledge of the operation of these engines. [4], [5]. Piston rings, investigated in this study, are some of the most demanded components in the operation of car engines and, as it is known by means of the Stribeck Curve, the working regime of piston rings are quite critical and needs much attention, as their working is based on mixed lubrication.

Being so, considering that the comparative analysis of the piston rings of gasoline engines and flex-fuel engines through physical measurements (micrometer and pachymeter), and topographic (rugosimeter) and metallographic (microscope) analyses may shed light into some questions, these procedures, i.e., dimensional, rugosimetric and microscopic analyses, make up the practical portion of this research study.

\section{1) FUNDAMENTAL CONCEPTS}

According to ANFAVEA - National Inventory of Atmospheric Emissions by Road Automotive Vehicles, in 2003, the national automotive industry started manufacturing 
and commercializing flex-fuel engines in Brazil and the production increases every year, in parallel, in 2008, the production of alcohol engines began to fall to zero, as shown in figure 1. [6].

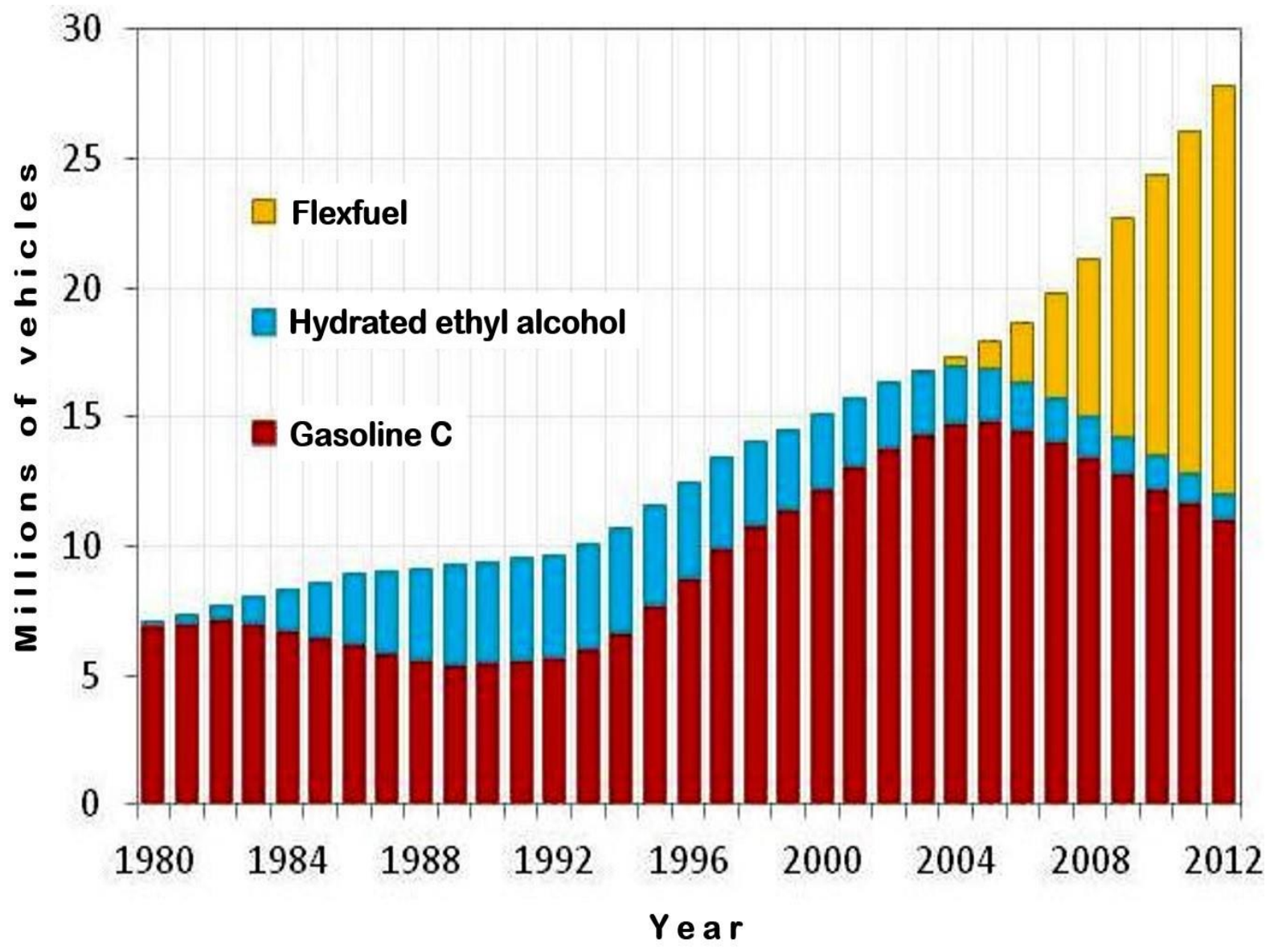

Figure 1: Evolution of the estimated fleet of automobiles by type of fuel. [6].

With the increasing fleet of flexfuel vehicles, numerous problems have appeared, and among them, the calibratable parameters have brought great challenges to the industry and engineers specialized in engine calibration.

As it stands out in the figure 2, in 2003 there were approximately 1,800 calibratable parameters in gasoline engines with electronic fuel injection, but by 2015 it already exceeded the 17,000 calibratable parameters in the flexfuel engines. [3].

The difficulty increases even more when the challenge is to calibrate more components or systems in less time due to evolution and technological development. 


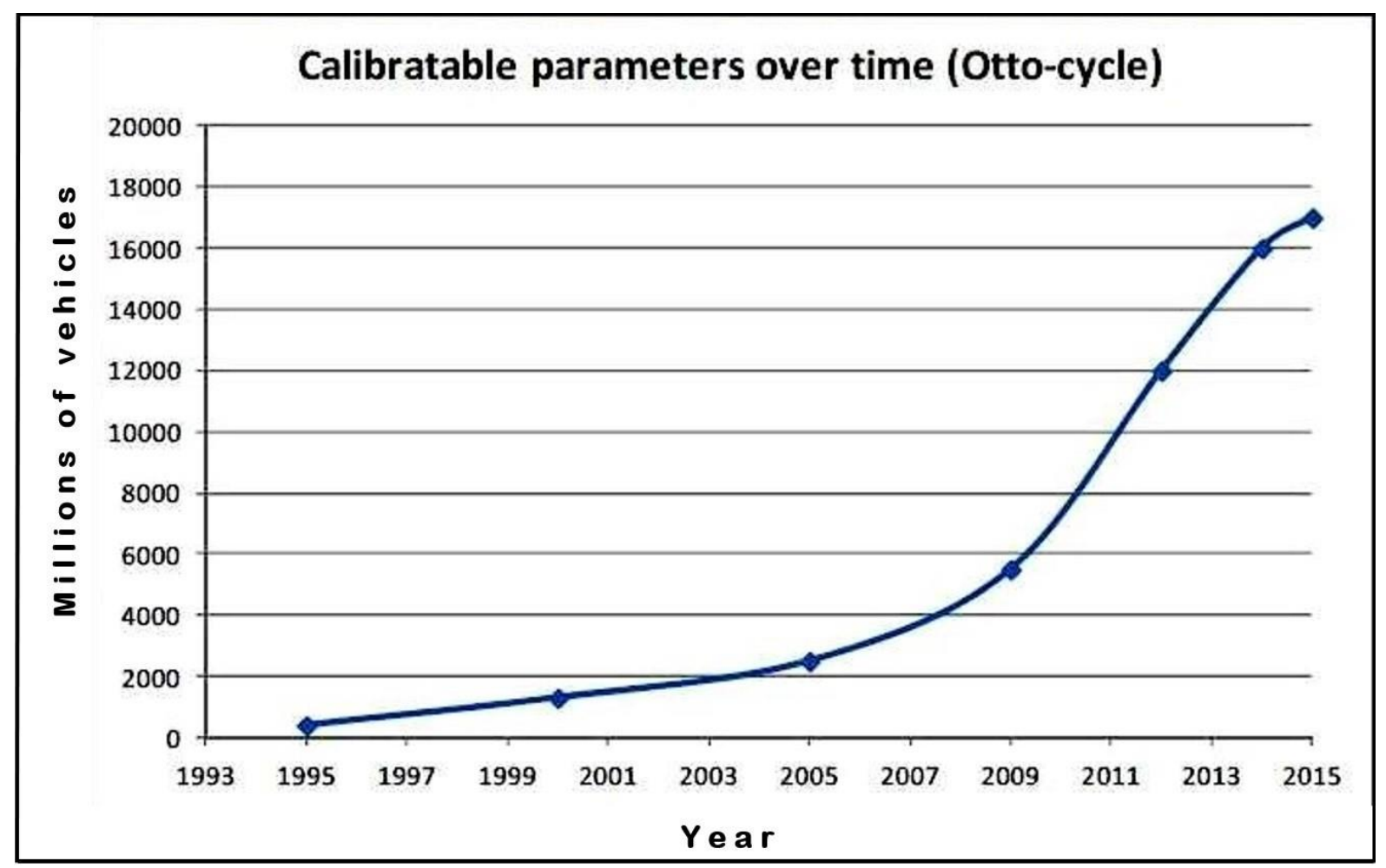

Figure 2: Calibratable parameters over time for the Otto cycle. [3].

As the example of difficulty, figure 3 presents some items liable to modifications for compatibility with the two fuels. [7].

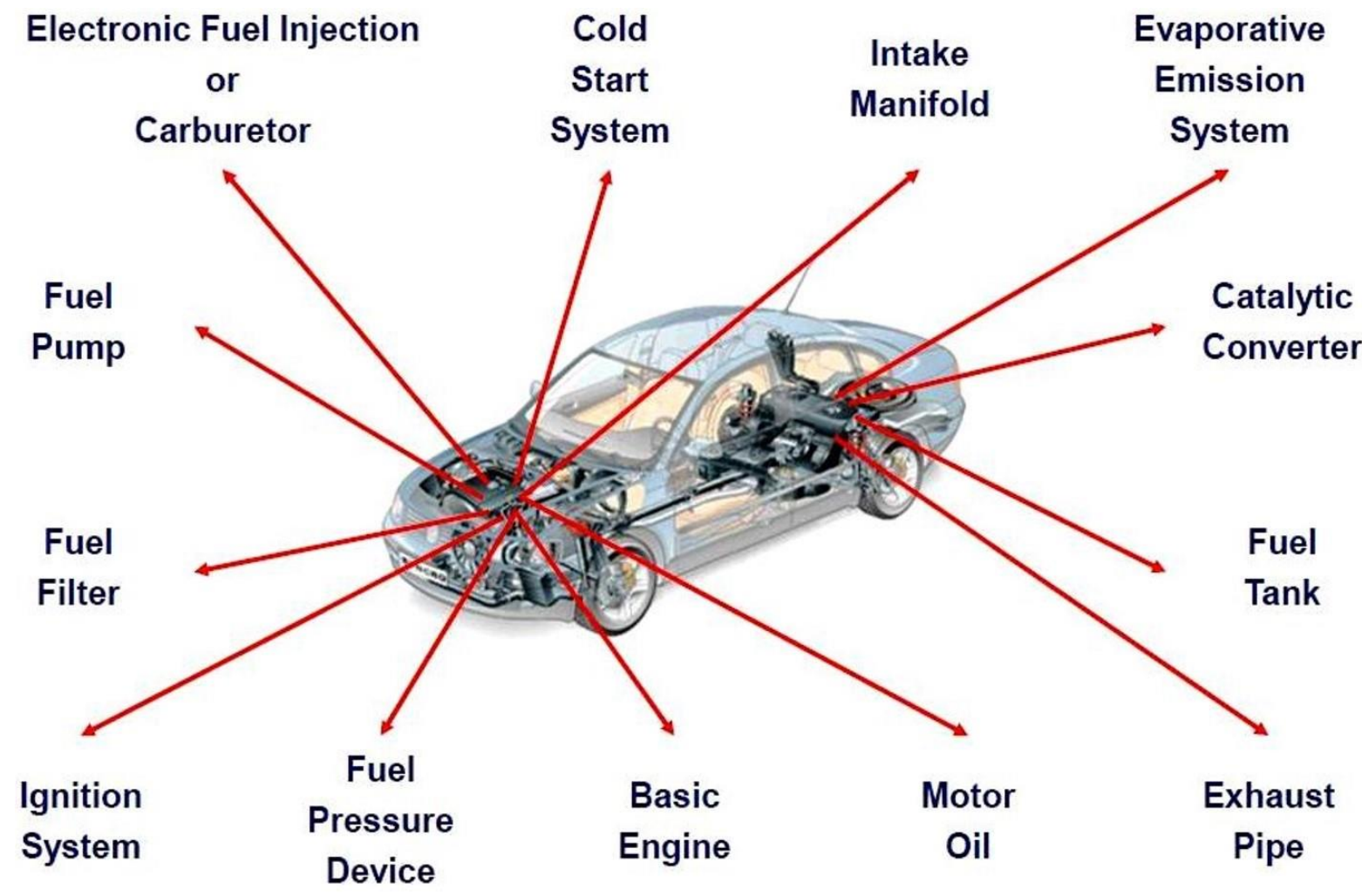

Figure 3: Items liable to modifications for compatibility with the two fuels: Gasoline and / or ethanol. 
As for piston rings, the oil film is crucial to its protection, as shown in figure 4, and, as we all know, it has the function of creating a protective interface between the ring and the cylinder and it must operate between the mixed and hydrodynamic lubrication regime. Due to its critical work and excessive load demand, a simple lubrication failure is sufficient to permanently damage the piston rings as well as the engine cylinder. It is worth noting that the oil film between the piston ring and the cylinder is only 0,5 to $4,0-\mu \mathrm{m}$ in thick.

The segment ring is one of the most demanded engine components, and perhaps one of the most difficult items to design, since it is practically impossible to test it while the engine is running.

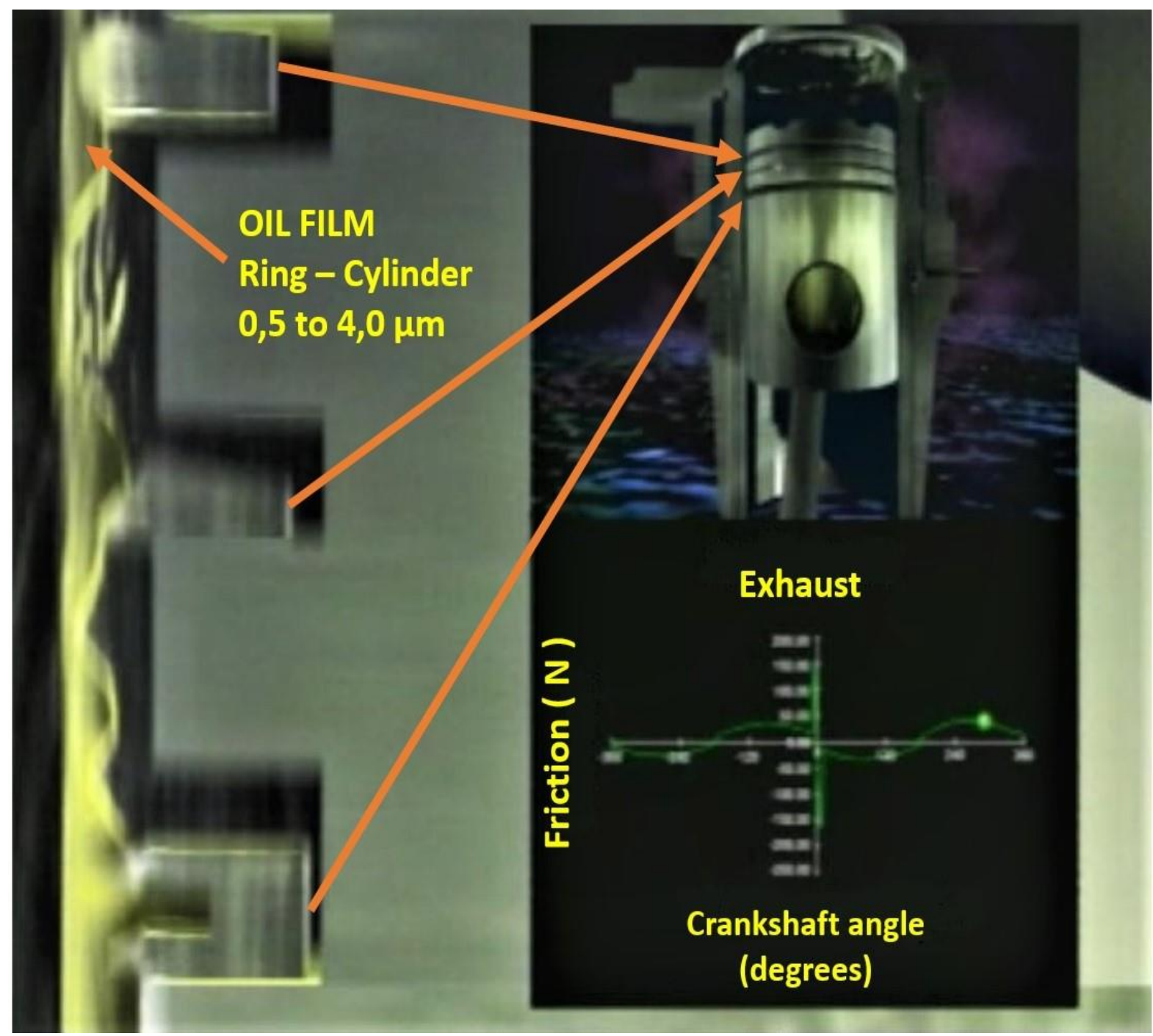

Figure 4: Piston-ring-cylinder tribological system. [8].

\section{2) MATERIALS AND METHODS}

The materials employed in the characterization are used and worn-out piston rings, of the first piston ring groove, also known as upper compression rings or fire rings. They were collected from an automobile repair and engine reconditioning shop, then 
they were cataloged by mileage, type of engine - gasoline or flex-fuel - year of manufacture and manufacturer. Figure 5.

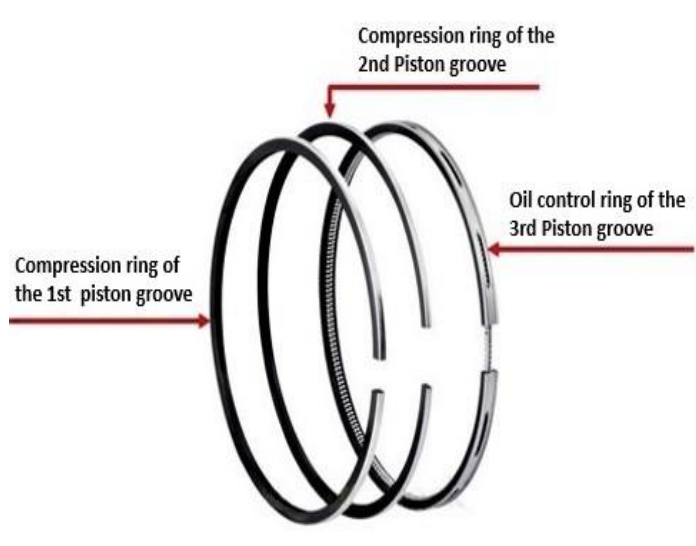

(a)

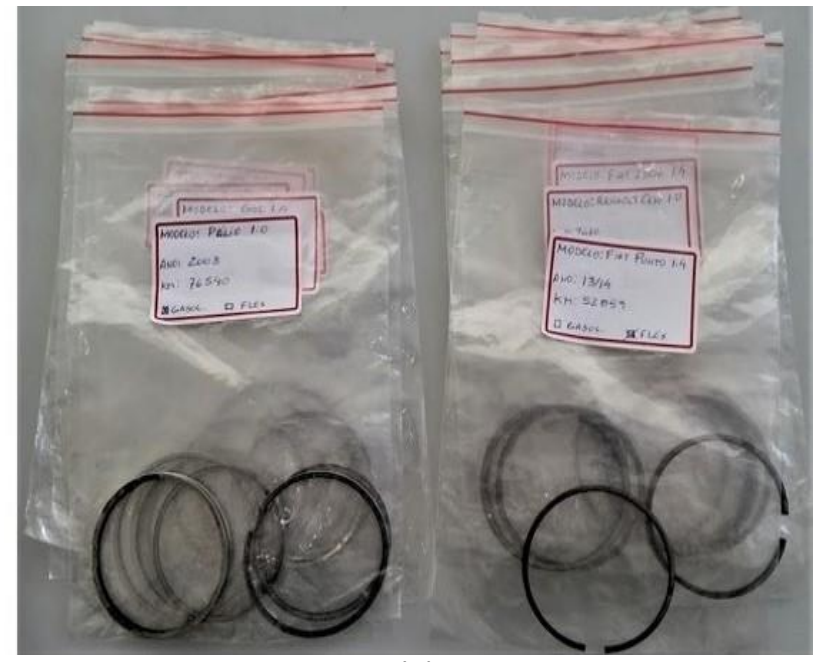

(b)

Figure 5: (a) - 1st Compression ring, 2nd compression ring and 3rd ring oil scraper. (b) - Samples acquired in an engine reconditioner.

Initially, there are two groups of engines. The group of gasoline engines and the group of flex-fuel engines. Six specimens of gasoline engine piston rings and 6 specimens of flex-fuel engine piston rings were randomly selected, totaling 12 specimens, as shown in table 1 . The analysis was performed in pairs, on the rings of the first row of the table, second row, third row and so on, due to similar mileage, since the objective was to compare the quality and amount of wear in the two groups.

Table 1: Distribution of engine, model, year and mileage groups.

\begin{tabular}{|ccc|ccc|}
\hline \multicolumn{2}{|c|}{ GASOLINE ENGINE } & \multicolumn{3}{c|}{ FLEXFUEL ENGINE } \\
\hline MODEL & YEAR & km & MODEL & YEAR & km \\
\hline Fiat Palio 1.0 & 2003 & 76540 & Fiat Punto 1.4 EVO & 2013 & 52859 \\
\hline Gol 1.0 & 2005 & 78643 & Renault Clio 1.0 & 2010 & 68736 \\
\hline Fiat Palio 1.0 & 1999 & 86886 & Fiat Ideia 1.4 & 2007 & 97440 \\
\hline Gol 1.0 & 2008 & 87898 & Fiat Strada 1.4 & 2006 & 98675 \\
\hline Gol 1.0 & 2007 & 102000 & Spacefox 1.6 & 2009 & 111000 \\
\hline Gol 2.0 & 1999 & 120000 & Fiat Doblo 1.3 16v & 2003 & 112000 \\
\hline
\end{tabular}

Prepared by the author, 2017. 


\section{1. $1^{\text {st }}$ characterization technique - Measurements with pachymeter and micrometer}

The first characterization technique, to compare the wear of the segment rings, included an analog pachymeter with a scale of 0 to $150 \mathrm{~mm}$ and Vernier scale with resolution of $0,05 \mathrm{~mm}$ for measuring the outer diameter of the segment rings and compare it with the measurements shown in the manufacturers' catalog. Then, the measurements were included in a table. All measurements were performed at least three times to minimize or avoid parallax errors and achieve the highest possible accuracy. Using a micrometer with a scale of 0 to $25 \mathrm{~mm}$ and a resolution of the $0.01 \mathrm{~mm}$ drum, the segment ring height and thickness were measured. Three measurements were also taken at point "A", three measurements at point "B" and three measurements at point " $\mathrm{C}$ " of the rings, to eliminate potential parallax errors and to obtain higher accuracy of measurement. This is shown in figure 6.

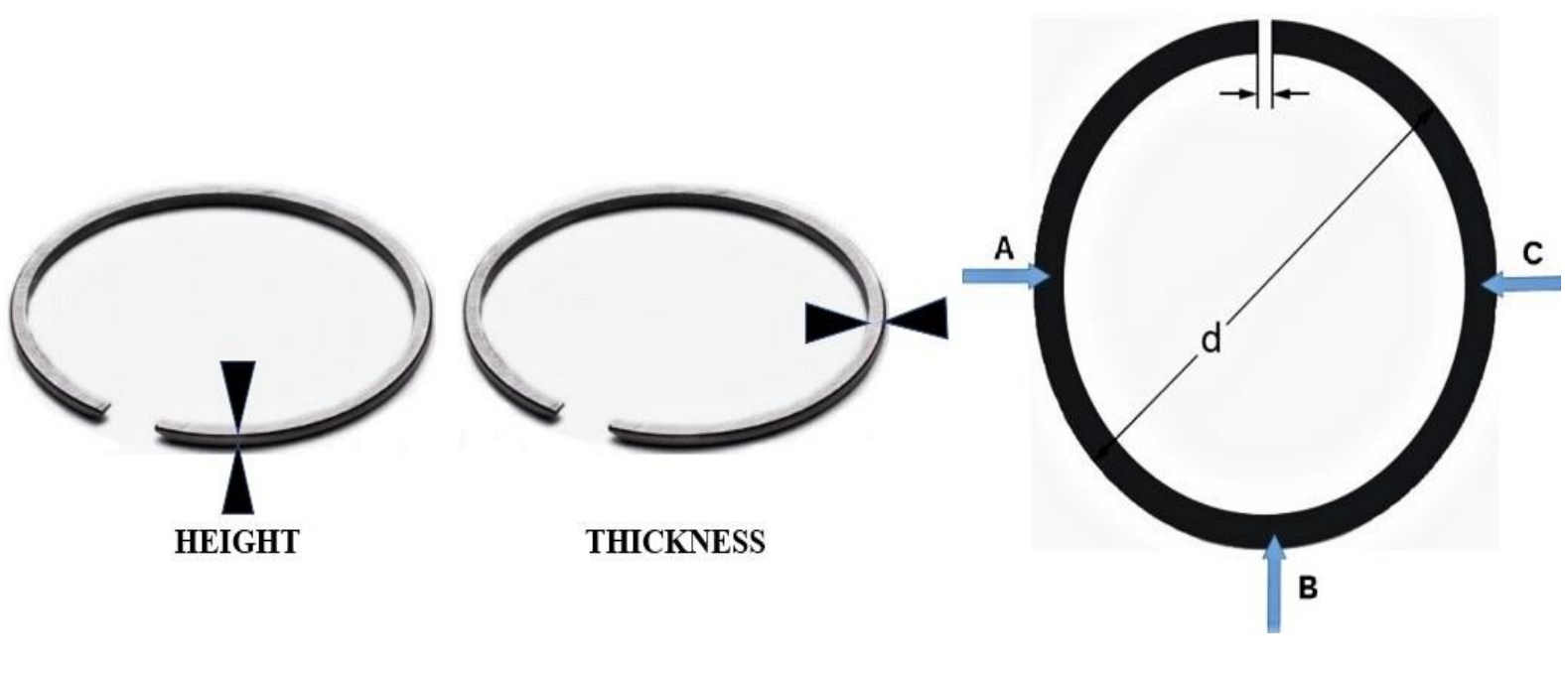

(a)

(b)

Figure 6: (a) Height and thickness of the segment ring. (b) - Height and thickness measurement points in the segment rings.

\section{2. $2^{\text {nd }}$ characterization technique - Measurements with rugosimeter}

The second characterization technique to compare the piston rings of the gasoline engines and rings of the flex-fuel engines used a rugosimeter to detect the surface roughness parameters, that is, the face of contact with the cylinder, determining the maximum values of the valleys (Rvk), the peaks (Rpk) and the mean values (Rk), [9], as shown in figure 7 , to determine Abbott-Firestone curve. The analysis was performed on the contact surface opposite to the ring opening, at an angle of $180^{\circ}$, at point $B$ of the piston ring, in the 12 specimens. The equipment was calibrated to 1997 ISO Standard with GAUSS filter - (Cutoff value $\lambda c 2,5$ - Displacement velocity 0.5 $\mathrm{mm} / \mathrm{s}$ - Setup range of "AUTO" measurement). 


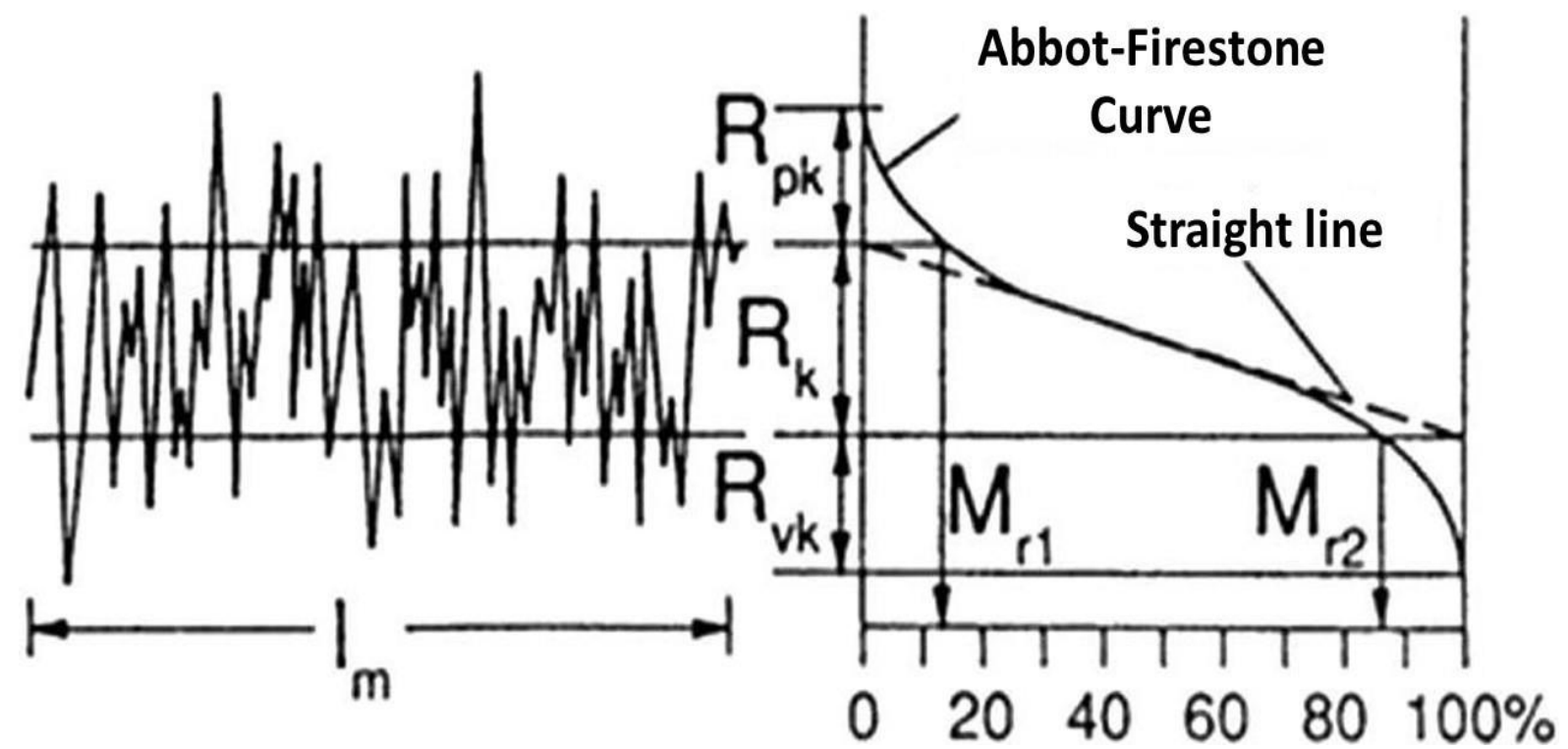

Figure 7: Abbot-Firestone curve or contact fraction curve. [9].

\section{3. $3^{\text {rd }}$ characterization technique - Microscopic analysis}

Figure 8 shows the third characterization technique, using Scanning Electron Microscopy (SEM), QUANTA FEG-250 SEM model with Energy Dispersive X-ray Spectroscopy (EDS) microanalysis.
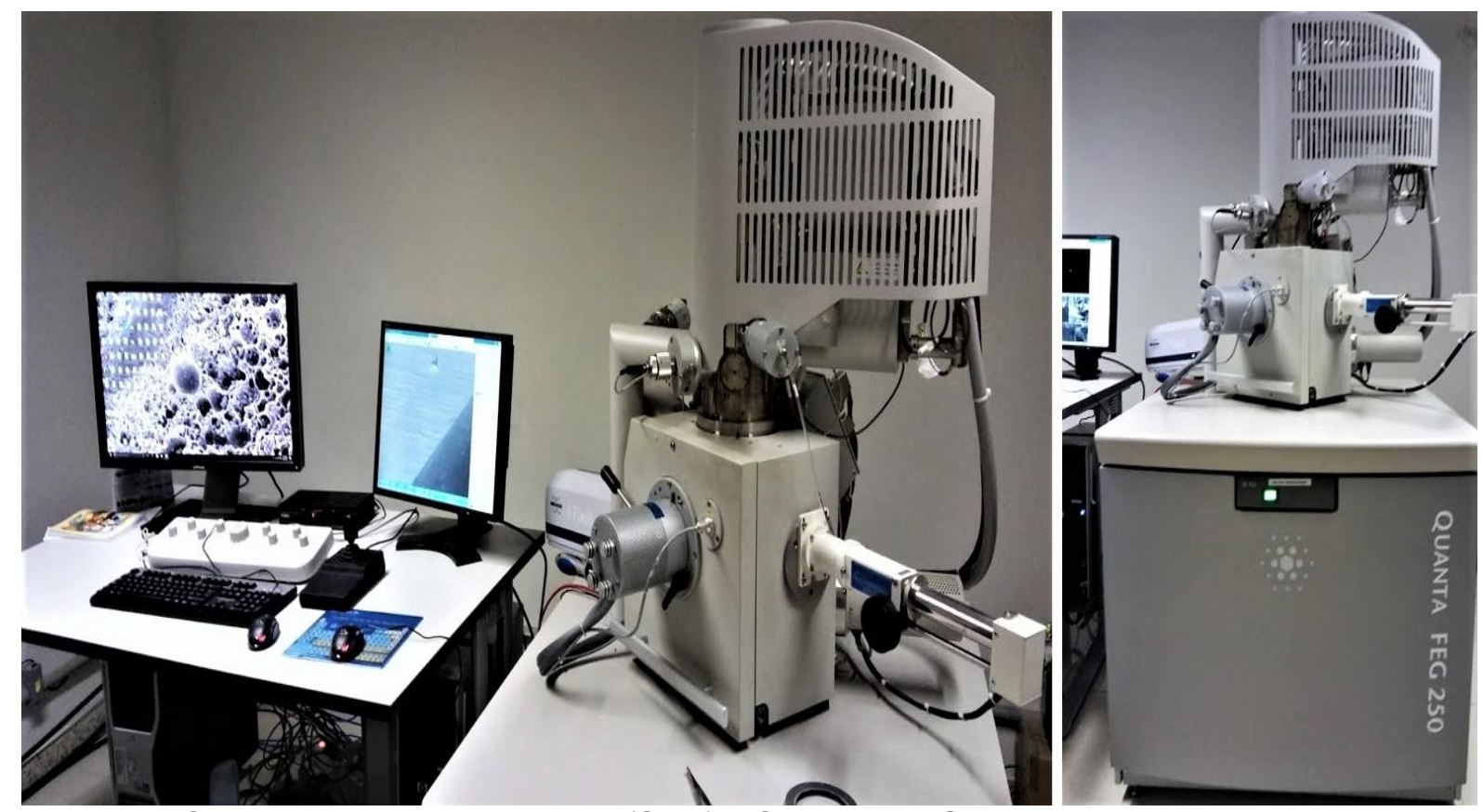

Figure 8: Scanning Electron Microscopy (SEM) - QUANTA FEG-250 with Energy Dispersive X-ray Spectroscopy (EDS) microanalysis.

Microscopic analysis was performed to determine the type of base metal and the surface treatment according to the steps shown in figure 9 . 


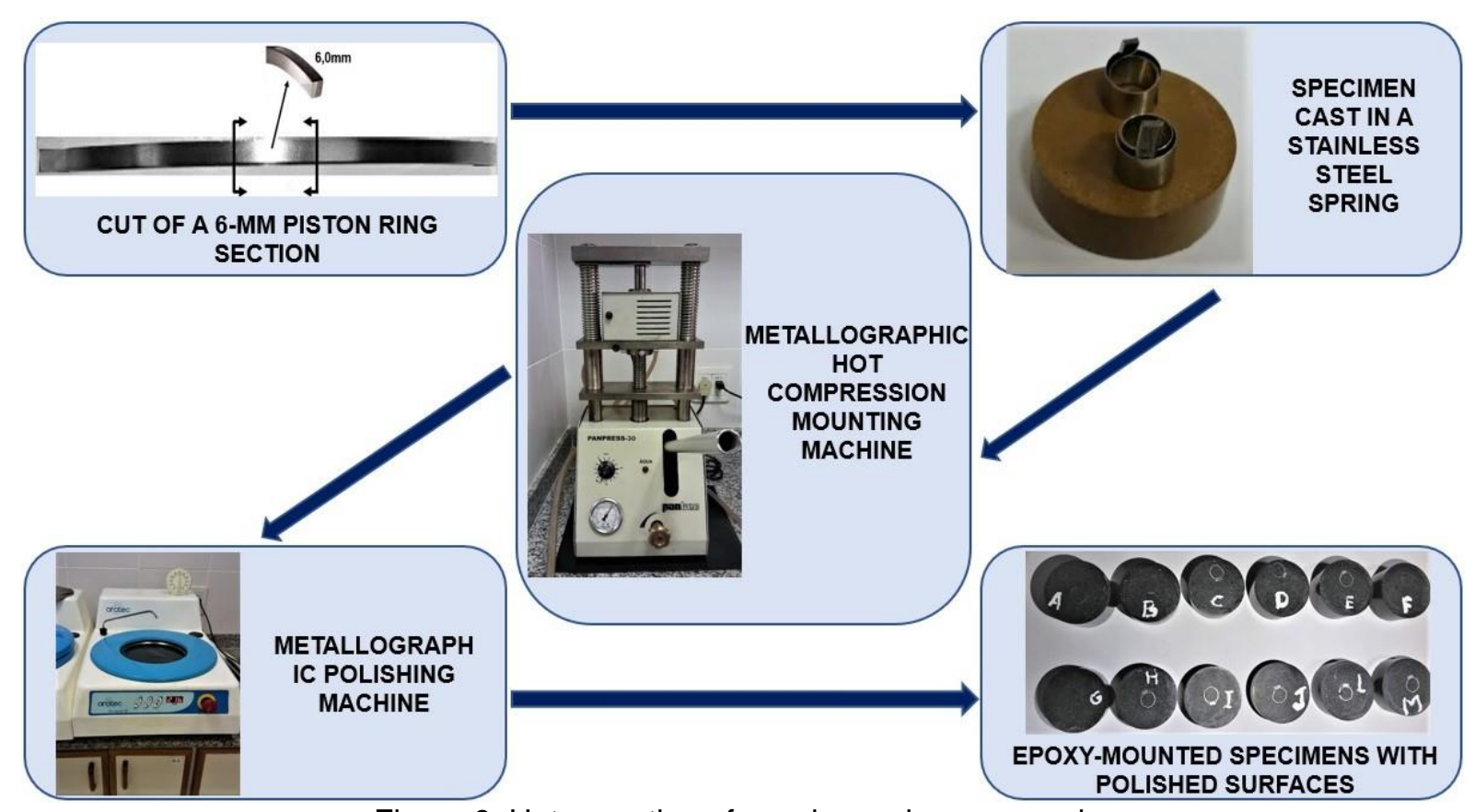

Figure 9: Hot mounting of specimens in epoxy resin.

\section{3) RESULTS AND DISCUSSION}

\subsection{Results of measurements with micrometer and pachymeter}

Table 2 shows the original diameter, height and width of the gasoline piston rings according to the manufacturer, as well as the year of manufacture and motorization according to the manufacturers' brands. [10].

Table 2: Specifications of the piston rings of gasoline engines.

\begin{tabular}{|c|c|c|c|c|c|c|c|}
\hline \multirow[b]{2}{*}{$\begin{array}{l}\text { Marca - Motor - Modelo } \\
\text { Application - Engine - Model } \\
\text { Marca - Motor - Modelo }\end{array}$} & \multirow[b]{2}{*}{$\begin{array}{l}\text { Ano } \\
\text { Year } \\
\text { Año }\end{array}$} & & & & \multirow[b]{2}{*}{-1} & \multicolumn{2}{|c|}{ PREMIUM } \\
\hline & & & & & & $\begin{array}{l}\text { METAL LEVE } \\
\text { MAHLE }\end{array}$ & $\begin{array}{l}\text { Tipos } \\
\text { Types } \\
\text { Tipos }\end{array}$ \\
\hline $\begin{array}{l}\text { Fire } 1.0 \mathrm{~L} 8 \mathrm{~V} / 16 \mathrm{~V} \\
\text { Palio }\end{array}$ & 2003 & 70,00 & 4 & $\begin{array}{l}1,20 \\
1,20 \\
2,50\end{array}$ & $\begin{array}{l}3,05 \\
3,05 \\
2,98\end{array}$ & $\begin{array}{l}\text { TD.7508 } \\
\text { STD/ } 0,20 / \\
0,40 / 0,60\end{array}$ & $\begin{array}{l}\text { E4 } \\
T 3 \\
86 T\end{array}$ \\
\hline $\begin{array}{l}\text { Motor AT 1.0L } 16 \mathrm{~V} \mathrm{Mi} \mathrm{-} \mathrm{Gol,} \mathrm{Parati} \\
\text { Aspirado / Turbo }\end{array}$ & 2005 & 67,10 & 4 & $\begin{array}{l}1,20 \\
1,50 \\
2,00\end{array}$ & $\begin{array}{l}2,65 \\
2,80 \\
3,19\end{array}$ & $\begin{array}{l}\text { TA.7251 } \\
\text { STD/ } 0,25 / \\
0,50 / 0,75\end{array}$ & $\begin{array}{l}\text { SL } \\
\text { T6 } \\
\text { C81 }\end{array}$ \\
\hline $\begin{array}{l}1000 / 1500 \text { - Palio (Gasolina/ } \\
\text { Álcool) }\end{array}$ & 1999 & 76,00 & 4 & $\begin{array}{l}1,50 \\
1,50 \\
3,00\end{array}$ & $\begin{array}{l}3,30 \\
3,30 \\
3,63\end{array}$ & $\begin{array}{l}\text { DD.7391 } \\
\text { STD/ } 0,40 / \\
0,60\end{array}$ & $\begin{array}{l}\text { CE4 } \\
\text { T6 } \\
87\end{array}$ \\
\hline $\begin{array}{l}\text { Motor AT 1.0L } 16 \mathrm{~V} \mathrm{Mi} \mathrm{-} \mathrm{Gol,} \mathrm{Parati} \\
\text { Aspirado / Turbo }\end{array}$ & 2008 & 67,10 & 4 & $\begin{array}{l}1,20 \\
1,50 \\
2,00\end{array}$ & $\begin{array}{l}2,65 \\
2,80 \\
3,19\end{array}$ & $\begin{array}{l}\text { TA.7251 } \\
\text { STD/ } 0.25 / \\
0,50 / 0,75\end{array}$ & $\begin{array}{l}\text { SL } \\
\text { T6 } \\
\text { C81 }\end{array}$ \\
\hline $\begin{array}{l}\text { Motor AT 1.0L } 16 \mathrm{~V} \mathrm{Mi} \mathrm{-} \mathrm{Gol,} \mathrm{Parati} \\
\text { Aspirado / Turbo }\end{array}$ & 2007 & 67,10 & 4 & $\begin{array}{l}1,20 \\
1,50 \\
2,00\end{array}$ & $\begin{array}{l}2,65 \\
2,80 \\
3,19\end{array}$ & $\begin{array}{l}\text { TA.7251 } \\
\text { STD/ } 0.25 / \\
0,50 / 0,75\end{array}$ & $\begin{array}{l}\mathrm{SL} \\
\mathrm{T} 6 \\
\mathrm{C} 81\end{array}$ \\
\hline $\begin{array}{l}\text { VW AP } 2000 \text { Álcool / Gasolina } \\
\text { Gol } 2.0\end{array}$ & 1999 & 82,50 & 4 & $\begin{array}{l}1,50 \\
1,50 \\
2,00\end{array}$ & $\begin{array}{l}3,35 \\
3,55 \\
3,28\end{array}$ & $\begin{array}{l}\text { DT.7072 } \\
\text { STD/ } 0,25 / \\
0,50\end{array}$ & $\begin{array}{l}\text { CE } \\
\text { T6 } \\
86\end{array}$ \\
\hline
\end{tabular}

Prepared by the author, 2017. 
Table 3 below shows the resulting height, width and diameter measurements of gasoline engine piston rings. The diameter measurements were taken by pachymeter and the height and thickness measurements of the worn-out rings were taken by micrometer, respecting the standards applicable to metrology laboratories.

Table 3: Results of measurements of the piston rings of gasoline engines with best data arrangement.

\begin{tabular}{|c|c|c|c|c|c|c|c|c|c|c|c|c|}
\hline \multicolumn{3}{|c|}{ GASOLINE ENGINE } & $\begin{array}{c}\text { NEW RING } \\
\text { HEIGHT } \\
\text { (mm) }\end{array}$ & $\begin{array}{c}\text { USED } \\
\text { RING } \\
\text { HEIGHT } \\
\text { (mm) }\end{array}$ & $\begin{array}{c}\Delta \\
(\mathrm{D} \cdot \mathrm{E}) \\
(\mathrm{mm})\end{array}$ & $\begin{array}{c}\Delta \% \\
\text { (D-E) }\end{array}$ & $\begin{array}{c}\text { NEW RING } \\
\text { THICKNESS } \\
(\mathrm{mm})\end{array}$ & $\begin{array}{c}\text { USED } \\
\text { RING } \\
\text { THICKNESS } \\
\text { (mm) }\end{array}$ & $\begin{array}{c}\Delta \\
(\mathrm{H} \cdot \mathrm{l}) \\
(\mathrm{mm})\end{array}$ & $\begin{array}{c}\Delta \% \\
(H-1)\end{array}$ & $\begin{array}{c}\text { DIAMETER } \\
\text { OF THE } \\
\text { NEW RING } \\
\text { (mm) } \\
\end{array}$ & $\begin{array}{c}\text { DIAMETER } \\
\text { OF THE } \\
\text { USED RING } \\
\text { (mm) }\end{array}$ \\
\hline MODEL & YEAR & $\mathrm{km}$ & & & & & & & & & & \\
\hline & & & & & & & & & & & & \\
\hline Fiat Palio 1.0 & 2003 & 76540 & 1,20 & 1,16 & 0,04 & $-3,33$ & 3,05 & 2,92 & 0,13 & $-4,26$ & 70,00 & 69,75 \\
\hline Gol 1.0 & 2005 & 78643 & 1,20 & 1,17 & 0,03 & $-2,50$ & 2,65 & 2,45 & 0,20 & $-7,55$ & 67,10 & 66,70 \\
\hline Fiat Palio 1.0 & 1999 & 86886 & 1,50 & 1,46 & 0,04 & $-2,67$ & 3,30 & 3,12 & 0,18 & $-5,45$ & 76,00 & 75,65 \\
\hline Gol 1,0 & 2008 & 87898 & 1,20 & 1,18 & 0,02 & $-1,67$ & 2,65 & 2,46 & 0,19 & $-7,17$ & 67,10 & 66,90 \\
\hline Gol 1.0 & 2007 & 102000 & 1,20 & 0,97 & 0,23 & $-19,17$ & 2,65 & 2,35 & 0,30 & $-11,32$ & 67,10 & 66,50 \\
\hline Gol 2.0 & 1999 & 120000 & 1.50 & 1.45 & 0.05 & $-3,33$ & 3.35 & 3.32 & 0.03 & -0.90 & 82.50 & 82.45 \\
\hline
\end{tabular}

Table 4, below, shows the original diameter, height and width of the original piston rings of the flex-fuel engines. [10].

Table 4: Specifications of the piston rings of flexfuel engines.

\begin{tabular}{|c|c|c|c|c|c|c|c|}
\hline \multirow[b]{2}{*}{$\begin{array}{l}\text { Marca - Motor - Modelo } \\
\text { Application - Engine - Model } \\
\text { Marca - Motor - Modelo }\end{array}$} & \multirow[b]{2}{*}{$\begin{array}{l}\text { Ano } \\
\text { Year } \\
\text { Año }\end{array}$} & \multirow[b]{2}{*}{$\varnothing$} & \multirow[b]{2}{*}{$=$} & \multirow[b]{2}{*}{1} & \multirow[b]{2}{*}{$-F$} & \multicolumn{2}{|c|}{ PREMIUM } \\
\hline & & & & & & $\begin{array}{l}\text { METAL LEVE } \\
\text { MAHLE }\end{array}$ & \begin{tabular}{|l|} 
Tipos \\
Types \\
Tipos
\end{tabular} \\
\hline $\begin{array}{l}\text { Motor Evo } 1.4 \mathrm{~L} 8 \mathrm{v} \text { Flex } \\
\text { Fiat Punto }\end{array}$ & 2013 & 72,00 & 4 & $\begin{array}{l}1,00 \\
1,00\end{array}$ & $\begin{array}{l}2,85 \\
3,15\end{array}$ & $\begin{array}{l}\text { TA. } 8760 \\
\text { STD }\end{array}$ & $\begin{array}{l}\text { E4 } \\
\text { IT7 }\end{array}$ \\
\hline Clio, Twingo Motor D7F & 2010 & 69,00 & 4 & $\begin{array}{l}1,50 \\
1,50 \\
2,50\end{array}$ & $\begin{array}{l}3,05 \\
3,05 \\
3,33\end{array}$ & $\begin{array}{l}\text { DD.7270 } \\
\text { STD } \\
\text { A18800 }\end{array}$ & $\begin{array}{l}\text { CE4 } \\
\text { T3 } \\
88\end{array}$ \\
\hline $\begin{array}{l}\text { Fire 1.4L Flex - Idea, Palio, Wee- } \\
\text { kend, Siena, Strada }\end{array}$ & 2007 & 72,00 & 4 & $\begin{array}{l}1,20 \\
1,20 \\
2,00\end{array}$ & $\begin{array}{l}3,05 \\
3,15 \\
2,83\end{array}$ & $\begin{array}{l}\text { TT. } 8330 \\
\text { STD/ } 0,40 / \\
0,60\end{array}$ & $\begin{array}{l}\text { E4 } \\
\text { T6 } \\
86 \mathrm{~T}\end{array}$ \\
\hline $\begin{array}{l}\text { Fire 1.4L Flex - Idea, Palio, Wee- } \\
\text { kend, Siena, Strada }\end{array}$ & 2006 & 72,00 & 4 & $\begin{array}{l}1,20 \\
1,20 \\
2,00\end{array}$ & $\begin{array}{l}3,05 \\
3,15 \\
2,83\end{array}$ & $\begin{array}{l}\text { TT.8330 } \\
\text { STD/ } 0,40 / \\
0,60\end{array}$ & $\begin{array}{l}\text { E4 } \\
\text { T6 } \\
86 \mathrm{~T}\end{array}$ \\
\hline $\begin{array}{l}\text { Motor EA } 1111.6 \mathrm{~L} 8 \mathrm{~V} \text { Flex Fuel - } \\
\text { Gol, Parati, Saveiro, Fox } \\
\text { Spacefox }\end{array}$ & 2009 & 76,50 & 4 & $\begin{array}{l}1,20 \\
1,50\end{array}$ & $\begin{array}{l}2,85 \\
3,30\end{array}$ & $\begin{array}{l}\text { TA.8126 } \\
\text { STD/ } 0,50\end{array}$ & $\begin{array}{l}\mathrm{SL} \\
\mathrm{T} 6\end{array}$ \\
\hline $\begin{array}{l}\text { Fire } 1.3 \mathrm{~L}-8 \mathrm{~V} / 16 \mathrm{~V} \\
\text { Doblo }\end{array}$ & 2003 & 70,80 & 4 & $\begin{array}{l}1,20 \\
1,20 \\
2,50\end{array}$ & $\begin{array}{l}3,05 \\
3,05 \\
2,98\end{array}$ & $\begin{array}{l}\text { TD.7500 } \\
\text { STD/ 0,20/ } \\
0,40 / 0,60\end{array}$ & $\begin{array}{l}\text { SL4 } \\
\text { T3 } \\
86 \mathrm{~T}\end{array}$ \\
\hline
\end{tabular}

Prepared by the author, 2017. 
Table 5 shows the results of the measurements of height, width and diameter of the piston rings of the flex-fuel engines.

Table 5: Results of measurements of the piston rings of flex-fuel engines with best data arrangement.

\begin{tabular}{|c|c|c|c|c|c|c|c|c|c|c|c|c|}
\hline \multicolumn{3}{|c|}{ FLEXFUEL ENGINE } & \multirow{2}{*}{$\begin{array}{c}\text { NEW RING } \\
\text { HEIGHT } \\
\text { (mm) }\end{array}$} & \multirow{2}{*}{$\begin{array}{c}\text { USED } \\
\text { RING } \\
\text { HEIGHT } \\
(\mathrm{mm})\end{array}$} & \multirow{2}{*}{$\begin{array}{c}\Delta \\
(\mathrm{D}-\mathrm{E}) \\
(\mathrm{mm})\end{array}$} & \multirow{2}{*}{$\begin{array}{l}\Delta \% \\
\text { (D-E) }\end{array}$} & \multirow{2}{*}{$\begin{array}{c}\text { NEW RING } \\
\text { THICKNESS } \\
\text { (mm) }\end{array}$} & \multirow{2}{*}{$\begin{array}{c}\text { USED } \\
\text { RING } \\
\text { THICKNESS } \\
\text { (mm) }\end{array}$} & \multirow{2}{*}{$\begin{array}{c}\Delta \\
(\mathrm{H} \cdot \mathrm{l}) \\
(\mathrm{mm})\end{array}$} & \multirow{2}{*}{$\begin{array}{l}\Delta \% \\
(H-I)\end{array}$} & \multirow{2}{*}{$\begin{array}{c}\text { DIAMETER } \\
\text { OF THE } \\
\text { NEW RING } \\
(\mathrm{mm})\end{array}$} & \multirow{2}{*}{$\begin{array}{c}\text { DIAMETER } \\
\text { OF THE } \\
\text { USED RING } \\
(\mathrm{mm})\end{array}$} \\
\hline MODEL & YEAR & $\mathrm{km}$ & & & & & & & & & & \\
\hline Fiat Punto 1.4 EVO & 2013 & 52859 & 1,00 & 0,98 & 0,02 & $-2,00$ & 2,85 & 2,74 & 0,11 & $-3,86$ & 72,00 & 71,80 \\
\hline Renault CLIO 1.0 & 2010 & 68736 & 1,50 & 1,48 & 0,02 & $-1,33$ & 3,05 & 2,75 & 0,30 & $-9,84$ & 69,00 & 68,40 \\
\hline Fiat Ideia 1.4 & 2007 & 97440 & 1,20 & 1,18 & 0,02 & $-1,67$ & 3,05 & 2,91 & 0,14 & $-4,59$ & 72,00 & 71,80 \\
\hline Fiat Strada 1,4 & 2006 & 98675 & 1,20 & 1,18 & 0,02 & $-1,67$ & 3,05 & 3,04 & 0,01 & $-0,33$ & 72,00 & 71,90 \\
\hline Spacefox 1.6 & 2009 & 111000 & 1,20 & 1,17 & 0,03 & $-2,50$ & 2,88 & 2,70 & 0,18 & $-6,25$ & 76,50 & 76,20 \\
\hline Fiat Doblo $1.316 \mathrm{~V}$ & 2003 & 112000 & 1,20 & 1,16 & 0,04 & $-3,33$ & 3,05 & 2,92 & 0,13 & $-4,26$ & 70,80 & 70,55 \\
\hline
\end{tabular}

Prepared by the author, 2017.

\subsection{Results of the rugosimetric analysis}

Table 6 presents the distribution of the results of laboratory evaluations using a rugosimeter, which analyzed the surface roughness of the surface of gasoline engine piston rings. The table shows the Rvk, Rk and Rpk values.

Table 6: Results of the values of Rvk, Rk and Rpk found in the rugosimetric analysis of the gasoline engines.

\begin{tabular}{|c|c|c|c|c|c|}
\hline \multicolumn{3}{|c|}{ GASOLINE ENGINE } & Rvk & Rk & Rpk \\
\hline MODEL & YEAR & km & $\mu \mathrm{m}$ & $\mu \mathrm{m}$ & $\mu \mathrm{m}$ \\
\hline Fiat Palio 1.0 & 2003 & 76540 & 0,417 & 0,710 & 2,562 \\
\hline Gol 1.0 & 2005 & 78643 & 0,445 & 0,692 & 2,729 \\
\hline Fiat Palio 1.0 & 1999 & 86886 & 0,429 & 0,718 & 2,148 \\
\hline Gol 1,0 & 2008 & 87898 & 0,518 & 0,743 & 2,474 \\
\hline Gol 1.0 & 2007 & 102000 & 0,382 & 0,685 & 2,848 \\
\hline Gol 2.0 & 1999 & 120000 & 0,376 & 0,645 & 2,216 \\
\hline
\end{tabular}

Prepared by the author, 2017.

Also, the bar chart shown in figure 10, where the rugosimetric values. The column on the left shows the values in $\mu \mathrm{m}$ and in the bottom row, numbers 1, 2, 3, 4, 5 and 6 represent the engines of the vehicles in the order arranged in the table. 


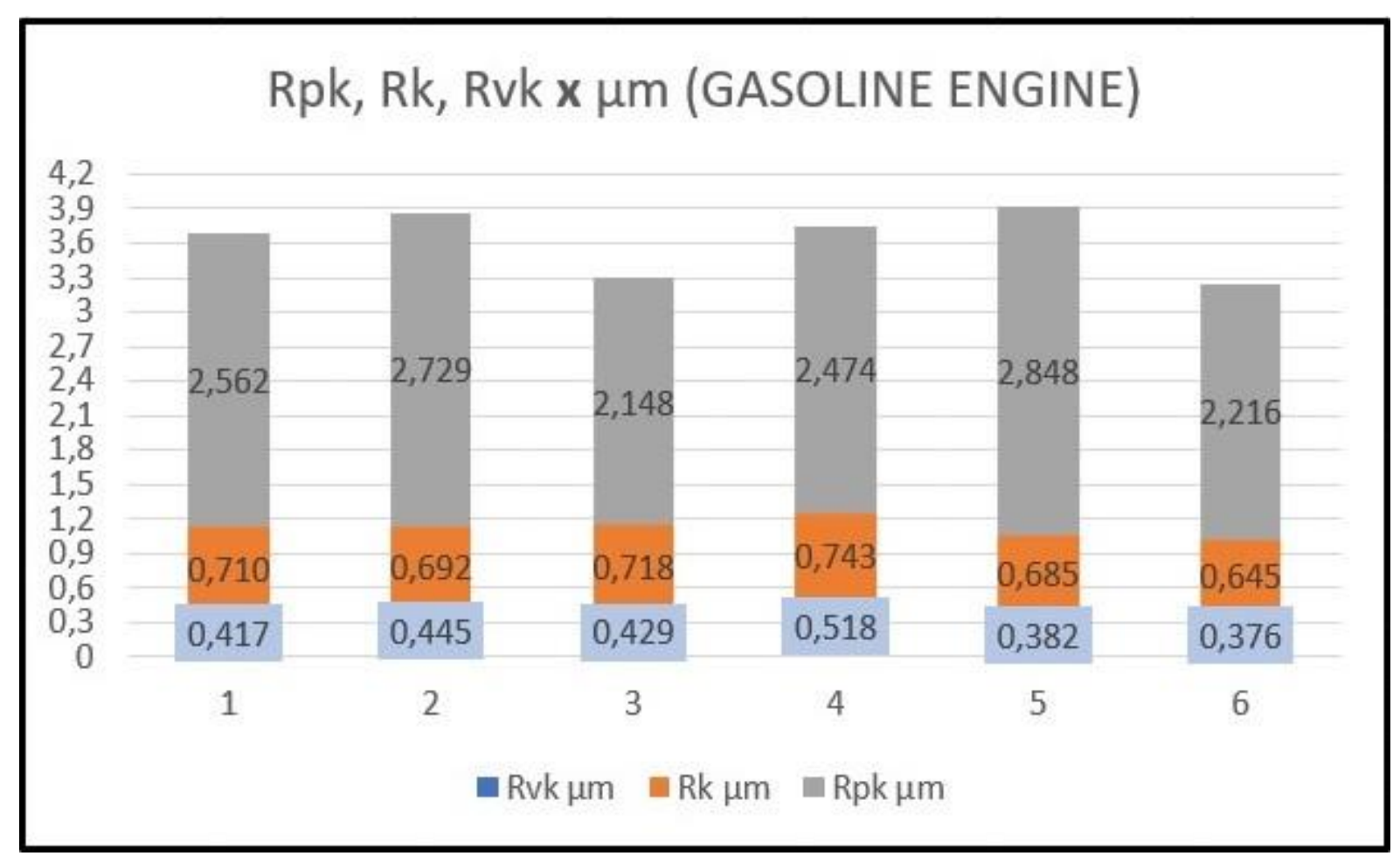

Figure 10: Chart of Rpk, Rk and Rvk X $\mu \mathrm{m}$ results for the rings of gasoline engines.

Table 7 below shows the distribution of the results of laboratory evaluations using a rugosimeter to analyze the surface roughness of the piston rings of flex-fuel engine. The table shows the Rvk, Rk and Rpk values.

The graph of columns is also observed in figure 7 , where the rugosimetric values are shown. In the left vertical legend are the values in $\mu \mathrm{m}$ and in the lower horizontal legend, the numbers $1,2,3,4,5$ and 6 represent the engines of the vehicles in the order arranged in the table.

Table 7: Results of the values of Rvk, Rk and Rpk found in the rugosimetric analysis of the flexfuel engines.

\begin{tabular}{|c|c|c|c|c|c|}
\hline \multicolumn{3}{|c|}{ FLEXFUEL ENGINE } & Rvk & Rk & Rpk \\
\hline MODEL & YEAR & km & $\mu \mathrm{m}$ & $\mu \mathrm{m}$ & $\mu \mathrm{m}$ \\
\hline Fiat Punto 1.4 EVO & 2014 & 52859 & 1,411 & 0,748 & 2,858 \\
\hline Renault CLIO 1.0 & 2010 & 68736 & 1,031 & 1,082 & 2,335 \\
\hline Fiat Ideia 1.4 & 2007 & 97440 & 0,319 & 0,492 & 2,415 \\
\hline Fiat Strada 1,4 & 2006 & 98675 & 0,268 & 0,902 & 2,501 \\
\hline Spacefox 1.6 & 2010 & 111000 & 0,422 & 0,422 & 1,894 \\
\hline Fiat Doblo 1.3 16v & 2003 & 112000 & 0,297 & 0,636 & 3,073
\end{tabular}

Prepared by the author, 2017. 
Also, the bar chart shown in figure 11 presents the rugorimetric values. The column on the left shows the values in $\mu \mathrm{m}$ and, in the bottom row, numbers 1, 2, 3, 4, 5 and 6 represent the engines of the vehicles in the order arranged in the table.

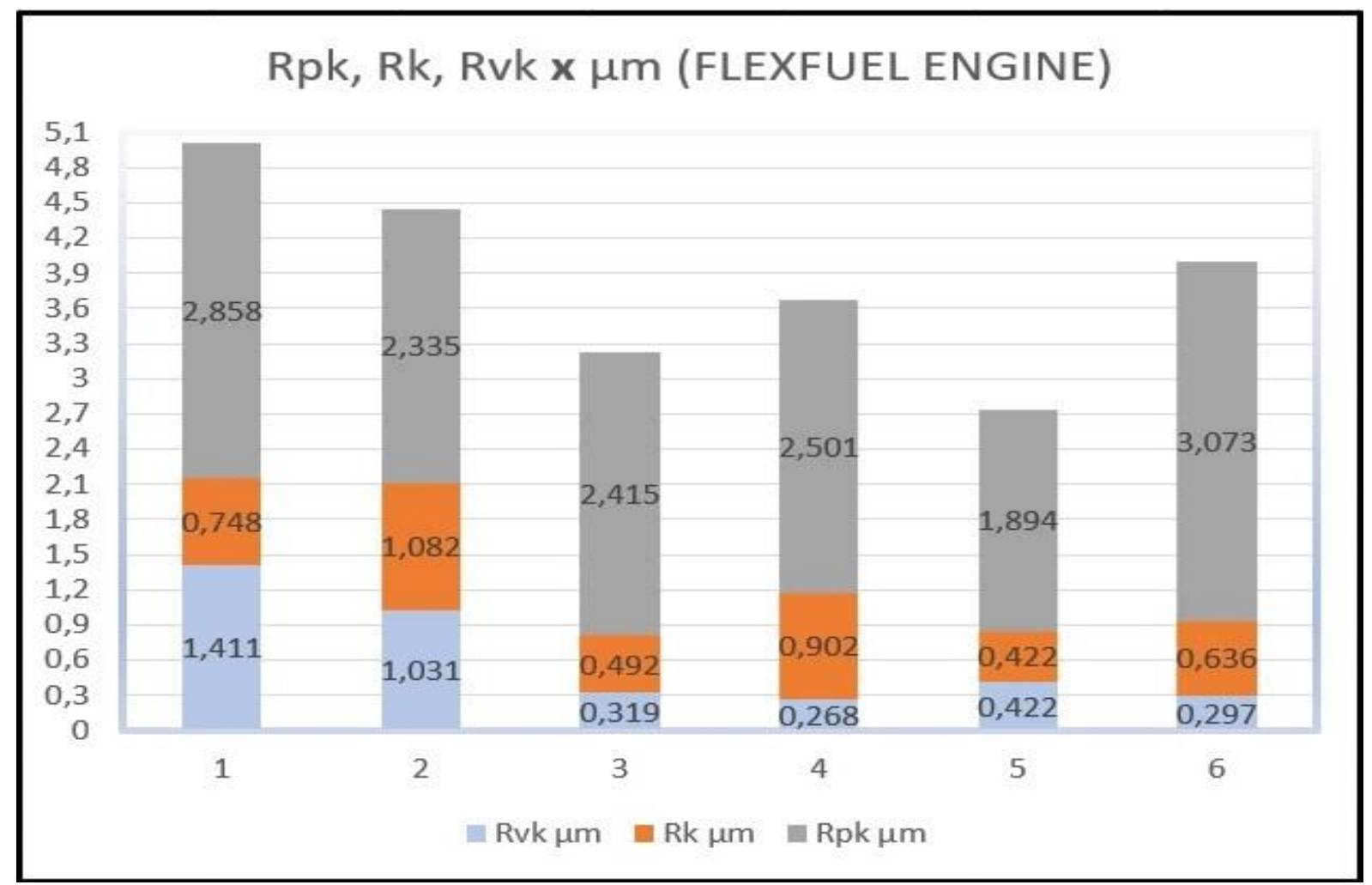

Figure 11: Chart of Rpk, Rk and Rvk X $\mu \mathrm{m}$ results for the rings of flex-fuel engines.

Thus, by analyzing the figures 10 and 11 , we can infer that the wear of the piston rings of the gasoline engines is more regular, therefore, inferences and forecasts of wear averages can be made with accuracy and reasonableness with regard to wear quality.

As for the piston rings of the flexfuel engines, wear occurs in a random and nonuniform way, with some unpredictability regarding wear quality.

\subsection{Result of measurements and microscopic analyzes}

The results of micrography are arranged in columns, following the same sequence adopted in this study, namely gasoline engines first $(A, B, C, D, E, F)$ then flex-fuel engines $(G, H, I, J, L, M)$. The left column shows the micrographs of the gasoline engines rings, and the right column shows the micrographs of the flex-fuel engines rings.

The analyzes were performed at the top of the ring in an attempt to observe the base metal, the deposition interface and the deposition metal which is the surface treatment layer according to figure 7.

Analyzing the table 8 , it can be seen that, although the specimens had had randomly collected in some engine rectifiers - making them to be of an unreliable origin and uncertain mileage - the micrography results are consistent with the segment ring manufacturer's specifications with respect to the base material. 

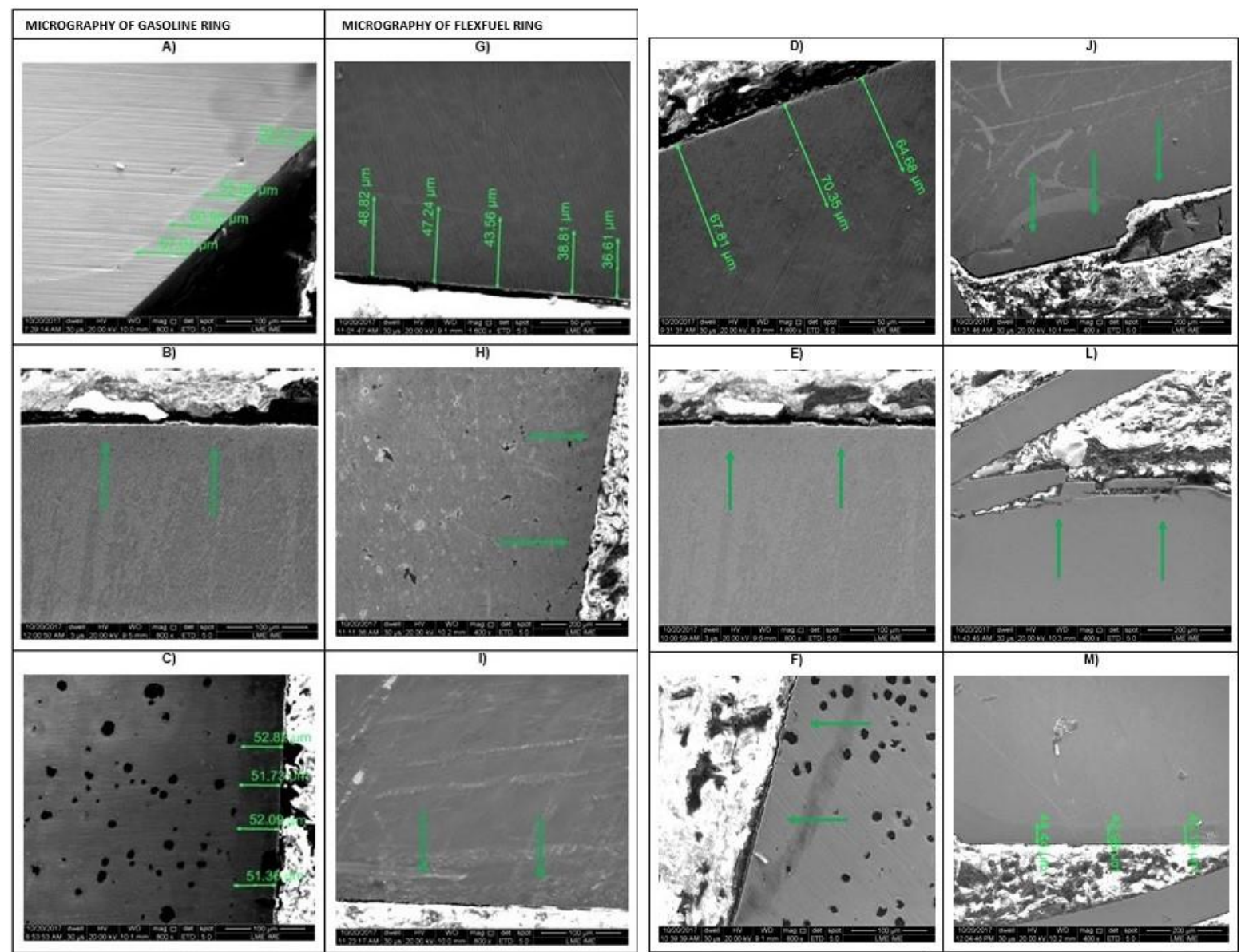

Figure 12: Micrography of gasoline and flex-fuel piston rings.

Table 8: Code of materials used in piston rings.

\begin{tabular}{|c|}
\hline GASOLINE ENGINE \\
\hline $\begin{array}{l}\text { Palio } 1.0-2003 \\
\text { CÓD.: TD. } 7508 \text { (Nitrided steel) }\end{array}$ \\
\hline $\begin{array}{l}\text { Gol } 1.0-2005 \\
\text { CÓD.: TA.7251 (Nitrided steel) }\end{array}$ \\
\hline $\begin{array}{l}\text { Palio 1.0 - } 1999 \\
\text { CÓD.: DD.7391 (Chromed nodular iron) }\end{array}$ \\
\hline $\begin{array}{l}\text { Gol } 1.0-2008 \\
\text { CÓD.: TA.7251 (Nitrided steel) }\end{array}$ \\
\hline $\begin{array}{l}\text { Gol } 1.0 \text { - } 2007 \\
\text { CÓD.: TA.7251 (Nitrided steel) }\end{array}$ \\
\hline $\begin{array}{l}\text { Gol 2.0 - } 1999 \\
\text { CóD.: DT.7072 (Chromed nodular iron) }\end{array}$ \\
\hline
\end{tabular}

FLEXFUEL ENGINE

Punto 1.4 - 2013/14 EVO

CÓD.: TA.8760 (Nitrided steel)

Clio 1.0 - 2010

CÓD.: DD.7270 (Chromed nodular iron)

Ideia 1.4- 2007

CÓD.: TT.8330 (Nitrided steel)

Strada $1.4-2006$

CÓD.: TT.8330 (Nitrided steel)

Spacefox 1.6 - 2009/10

CÓD.: TA.8126 (Nitrided steel)

Doblo 1.3-2003

CÓD.: TD.7500 (Nitrided steel)

Prepared by the author, 2017. 
Figures $A, D, G$ and $M$ show the nitrided surface treatment layer and figure $C$ presents the chromium layer in the nodular cast iron ring.

In specimens $B, E, F, H, I, J, L$, it was not possible to identify the surface treatment or coating layer applied to the rings. Specimens $L$ and $M$ suffered fractures and detachment of material during the inlay work. The rings of segments $B, E, J, L$, are made, apparently, from the same base material. Thus, microscopic analysis with EDS was performed in only one ring - the ring of segment B - to identify structural metallographic changes near the edge and more towards the interior or center of the material.

\section{CONCLUSION}

With the support of several collaborators, it was possible to demonstrate, through comparisons, that is, by conducting a strictly empirical work, the supposed results of different non-conforming wear in the materials of piston rings of gasoline engines and piston rings of flex-fuel engines, implying the phenomena of friction, lubrication, science and technology of materials and fuels, which are far from being fully unraveled and elucidated due to their great complexity and breadth.

The research conditions generated the conclusions explained below.

Regarding the measurements, we concluded that:

- The piston rings of gasoline engines, compared to each other, that is, within their group itself, do not show significant variations of wear.

- The piston rings of flex-fuel engines, compared to each other, that is, within their group itself, do not show significant variations of wear.

From the analysis of roughness profile, we concluded that:

- The Rvk values for the rings of gasoline engines are lower than the Rvk values for the rings of flex-fuel engines.

- The Rk values for gasoline engine rings are lower than the Rk values for flex-fuel engine rings.

- The Rpk values for gasoline engine rings are lower than the Rpk values for flex-fuel engine rings.

From the microscopic analysis, we concluded that:

- Despite some inaccuracies and uncertainties, the piston rings specimens of both gasoline engines and flex-fuel engines proved to be consistent and reliable since their characteristics are consistent with the base metal described in the manufacturer's

manual.

- Although some specimens of nitrided steel rings show surface treatment, four specimens of nitrided steel rings appear to have no surface treatment, but, to confirm this, it would be necessary to perform an EDS analysis on all components. - It should be noted that the values found are based on direct results of measurements, taking into account experimental test conditions.

Non-controllable factors that affect the analyses and specimens should also be taken into account, such as:

- Uncertainty regarding the actual mileage of the engines.

- Uncertainty regarding the fuel used in flex-fuel engines, whose ring specimens were tested, as some owners opt for using only gasoline over the life of the engine.

- The Gol 2.01999 - 120,000 km gasoline engine and the Fiat Strada 1.42006 - 
$98,675 \mathrm{~km}$ flex-fuel engine, with piston rings presenting little or almost no wear, raise suspicions. Those engines may have had recently undergone disassembly/grinding and, due to some maintenance or assembly failure, they had to be disassembled again, and the relatively new rings had to be replaced.

- There is uncertainty regarding the fuel used in both gasoline and flex-fuel engines. Natural gas It could have been used VNG - Vehicular Natural Gas, as this is a common practice these days.

\section{REFERENCES}

[1] Cortez, Luís Augusto Barbosa. PROÁLCOOL 40 ANOS - Universidades e Empresas: 40 anos de ciência e tecnologia para o etanol brasileiro. Ed. BLÜCHER 2016.

[2] BOSCH, MANUAL DE TECNOLOGIA AUTOMOTIVA. Ed. Edgard Blücher. 25a edição.

[3] Santos, L. R., Ferreira, R. P., Engenharia de motores flexfuel automotivos: Concepção, simulação e calibração. Apostila de curso SAE Brasil 2015.

[4] Tomanik, E., Tribologia em motores de combustão interna. Apostila de curso SAE Brasil 2016.

[5] ASM METAL HANDBOOK, Friction, lubrication and wear technology. Vol. 18 2002.

[6] ANFAVEA - National Inventory of Atmospheric Emissions by Road Automotive Vehicles. 2015.

[7] FIAT - Motor Show, Nova enciclopédia do automóvel. Ed. Três. 1999.

[8] SHELL Research \& Technology Centre - Thornton. 2016.

[9] ABNT, NBR ISO 4287, Rugosidade: Método do perfil - Termos, definições e parâmetros de rugosidade. 2002.

[10] MAHLE - Metal Leve, Catálogo de aplicações 2016. 